\title{
Cross-cultural adaptation and validation of the International Cooperative Ataxia Rating Scale (ICARS) to Brazilian Portuguese
}

\author{
Tradução para o português e validação da Escala Cooperativa Internacional para \\ Avaliação das Ataxias (ICARS)
}

Fernanda Aparecida Maggi', Pedro Braga-Neto ${ }^{2,3}$, Hsin Fen Chien4, Maria Thereza Drumond Gama', Flávio Moura Rezende Filho', Maria Luiza Saraiva-Pereira ${ }^{5,6}$, Laura Bannach Jardim ${ }^{5,7}$, Mariana Callil Voos ${ }^{8}$, José Luiz Pedroso', Orlando Graziani Povoas Barsottini'

\begin{abstract}
Introduction: The clinical assessment of patients with ataxias requires reliable scales. We aimed to translate, adapt and validate the International Cooperative Ataxia Rating Scale (ICARS) into Brazilian Portuguese. Methods: The steps of this study were forward translation, translation synthesis, backward translation, expert committee meeting, preliminary pilot testing and final assessment. Thirty patients were enrolled in the preliminary pilot testing and 61 patients were evaluated for construct validity, internal consistency, intra- and inter-rater reliability and external consistency. Results: This study showed good validity of the construct and high internal consistency for the full scale, except for the oculomotor domain (Cronbach's alpha $=0.316$, intraclass correlation coefficients intra- $=82.4 \%$ and inter- $=79.2 \%$ ). A high correlation with the Scale for the Assessment and Rating of Ataxia was observed. We found good intra-rater agreement and relative inter-rater disagreement, except in the posture and gait domain. Conclusion: The present ICARS version is adapted for the Brazilian culture and can be used to assess our ataxic patients.
\end{abstract}

Keywords: Spinocerebellar ataxias; translating; validation studies.

\section{RESUMO}

Introdução: A avaliação clínica de pacientes atáxicos requer instrumentos confiáveis. Nosso objetivo foi traduzir, adaptar culturalmente e validar a International Cooperative Ataxia Rating Scale (ICARS) para a língua portuguesa do Brasil. Métodos: As etapas foram tradução, síntese das traduções, retrotradução, comitê de especialistas, pré-teste e avaliação final. O pré-teste foi realizado com 30 pacientes. Outros 61 pacientes foram avaliados para validade do constructo, consistência interna, confiabilidade intra e interexaminadores e consistência externa. Resultados: Este estudo mostrou boa validade do constructo e alta consistência interna para o total da escala, exceto para o domínio Oculomotor (alfa de Cronbach $=0.316$, CClintra $=82.4 \%$ e CClinter $=79.2 \%$. . Alta correlação com a Scale for the Assessment and Rating of Ataxia foi observada. Nós encontramos boa concordância intraexaminador e relativa discordância interexaminadores, com exceção dos domínios postura e marcha. Conclusão: Esta versão da ICARS está adaptada para a cultura brasileira e pode ser usada em pacientes com ataxia.

Palavras-chave: Ataxias espinocerebelares; tradução; estudos de validação.

Spinocerebellar ataxias (SCAs) are a group of neurodegenerative and genetic diseases characterized by progressive cerebellar ataxia associated with oculomotor dysfunction, dysarthria, and variable degrees of pyramidal and extrapyramidal signs ${ }^{1,2}$. To date, 46 subtypes of SCAs have been described. They are related to more than 30 different genes and classified

\footnotetext{
${ }^{1}$ Universidade Federal de São Paulo, Departamento de Neurologia, Divisão de Neurologia Geral, São Paulo SP, Brasil;

${ }^{2}$ Universidade Federal do Ceará, Departamento de Medicina Clínica, Divisão de Neurologia;

${ }^{3}$ Universidade Estadual do Ceará, Centro de Ciências da Saúde, Fortaleza CE, Brasil;

«Universidade de São Paulo, Faculdade de Medicina, Intituto de Ortopedia e Traumatologia, São Paulo SP, Brasil;

${ }^{5}$ Hospital de Clínicas de Porto Alegre, Laboratório de Identificação Genética e Serviço de Genética Médica, Porto Alegre RS, Brasil;

${ }^{6}$ Universidade Federal do Rio Grande do Sul, Departamento de Bioquímica, Porto Alegre RS, Brasil;

7 Universidade Federal do Rio Grande do Sul, Departamento de Medicina Interna, Porto Alegre RS, Brasil;

${ }^{8}$ Universidade de São Paulo, Faculdade de Medicina, Departamento de Fisioterapia, Terapia Ocupacional e Fonoaudiologia, São Paulo SP, Brasil.

Correspondence: José Luiz Pedroso; Unidade de Ataxia, Departamento de Neurologia da UNIFESP; Rua Pedro de Toledo, 650; 04039-002 São Paulo SP, Brasil; E-mail:zeluizpedroso@yahoo.com,br

Conflict of interest: There is no conflict of interest to declare.

Support: This work did not receive any specific grant from funding agencies in the public, commercial, or non-profit sectors. The authors Pedro Braga-Neto, Maria Luiza Saraiva-Pereira and Laura Bannach Jardim were supported by the Conselho Nacional de Desenvolvimento Científico e Tecnológico (CNPq).

Received 28 April 2018; Received in final form 17 June 2018; Accepted 20 June 2018.
} 
from SCA1 to SCA463,4,5,6,7. The most common form is SCA3, also known as Machado-Joseph disease ${ }^{8}$.

Clinical scales are essential to assess the severity and progression of SCAs ${ }^{9}$. Braga-Neto et al. ${ }^{10}$ translated and validated the Brazilian version of the Scale for the Assessment and Rating of Ataxia (SARA), which evaluates and quantifies ataxia. The International Cooperative Ataxia Rating Scale (ICARS) is also frequently used in clinical practice to assess cerebellar symptoms, but it has not been available in Brazilian Portuguese. The ICARS was developed by Trouillas et al. ${ }^{11}$ and comprises 19 items, divided in four subscales: 1) posture and gait disturbances (items 1-7, score 0-34); 2) kinetic functions (items 8-14, score 0-52); 3) speech disorders (items 15-16, score 0-8); and 4) oculomotor disorders (items 17-19, score 0-6), along with a functional test (Archimedes spiral). The maximum possible score is 100 .

The ICARS was developed in English. Therefore, it needed to be translated and adapted (considering cultural characteristics) to be used in Brazil with the same content validity. The term "transcultural adaptation" involves a process that evaluates both idioms (original and translated) and cultural adaptation issues that emerge when a scale or questionnaire is used in distinct environments ${ }^{12,13}$. After that, the scale would need to be submitted for validation, which would evaluate the accuracy and reliability on a target population ${ }^{14}$.

There are several methods to verify the validity and reliability of a scale or questionnaire. Validity refers to an instrument to calculate a measure. Reliability is concerned with an instrument's ability to consistently measure a scale or questionnaire ${ }^{14,16}$. The construct validity is based on the measure accuracy of a variable. Individual characteristics should not interfere in the results of the scale ${ }^{15,16}$. Internal consistency tests the congruence between the items and the total score ${ }^{14}$. The inter- and intra-rater reliability tests the reproducibility of the scale ${ }^{17}$. The external consistency (or criterion validity) investigates the correlation with the scores of gold-standard scales ${ }^{16}$.

In this study, we aimed to translate and adapt the International Cooperative Ataxia Rating Scale (ICARS) to Brazilian Portuguese. We also examined measures of reliability and validity in patients with SCAs in the Brazilian population.

\section{METHODS}

\section{Evaluation and selection of patients}

Ninety-one patients from the division of General Neurology and Ataxia Unit, in the Department of Neurology, Universidade Federal de São Paulo - Brazil, were enrolled in this study. Thirty patients were invited to participate in the preliminary pilot testing of the translation and transcultural adaptation. The other 61 patients participated in the final validation process. Of the SCA subtypes of our sample, seven patients were diagnosed with SCA1 (7.7\%), 14 with SCA2
(15.4\%), 60 with SCA3 (66.0\%), eight with SCA6 (8.8\%) and two with SCA31 (2.1\%).

In the preliminary pilot validation phase, 31 (51\%) patients were male. Three were diagnosed with SCA1, 14 with SCA2, 38 (68\%) with SCA3, four with SCA6 and two with SCA31. The mean age was 43.8, ranging from 23 to 60 years. The mean age at symptoms onset was 35.4 years, ranging from 16 to 58 years. The mean disease duration was 8.3 years, ranging from 1 to 20 years, and most patients were ambulant (59\%).

Inclusion criteria included only adult patients with a clinical and molecularly-proven SCA, and age between 18 and 60 years. Exclusion criteria included cognitive impairment (patients who could not fully understand the tests), visual deficits, and patients who did not sign the participation consent form (for any reason). This project was approved by the Ethics Committee of the Federal University of São Paulo (protocol number 0451/2016). One of the developers of the scale, Dr. Mark Hallett, gave consent for this validation process for Brazilian Portuguese.

\section{Translation and transcultural adaptation of ICARS}

This study followed the method proposed by Beaton et al. ${ }^{13}$. The steps comprised forward translation, translation synthesis, backward translation, expert committee meeting, preliminary pilot testing and final assessment.

The translation was performed by two fluent English speakers, whose native language was Brazilian Portuguese. One of the translators had previous knowledge about the objectives and concepts of the ICARS and the other did not. Both translators performed a semantic (and not only literal) translation, using words that had the same cultural context. The two versions were synthesized in the first translated version. Two other translators, fluent in both languages, who were native English speakers and did not have previous knowledge about ataxia, translated the synthesized version back into English.

During the process of transcultural translation and adaptation, it was necessary to consult a speech therapist specialized in patients with SCAs, in order to verify if the translation of the phrase "A mischievous spectacle in Czechoslovakia" covered the same objectives of evaluation of dysarthria in the original scale, with equivalence between translations.

Written reports described all the steps and were analyzed at the expert meeting (which included researchers and translators). The semantic and transcultural equivalences between the translated and the original scales were established. Three neurologists then used the pretest version to evaluate 30 patients (two neurologists were highly experienced with ataxia diagnosis). Thereafter, another meeting discussed final adjustments and determined the final ICARS version in Brazilian Portuguese.

\section{Validation of the ICARS}

The validation of the ICARS involved construct validity, internal consistency, intra- and inter-rater reliability, external 
consistency and Bland-Altman analysis. The sample $(\mathrm{n}=61)$ was determined considering a $10 \%$ error. Significance level was alpha $=0.05(5 \%)$ and confidence intervals were $95 \%$. Parametric statistical tests were used, because data were continuous and had normal distribution. Statistical analysis was performed using SPSS V20, Minitab 16 and Microsoft Office Excel 2010 software.

Construct validity involved the comparisons by analyses of variance, of subgroups of male and female patients, of partial and total scores. Pearson's correlation coefficients investigated the relationships between partial and total scores and age. Internal consistency was expressed by Cronbach's alpha correlation coefficient between partial and total scores. The first evaluation of each patient was used in these calculations. Cronbach's alpha coefficients range from 0 to 1 . Values close to 1 suggest good internal consistency and reliability. Coefficients above 0.80 are considered acceptable ${ }^{18}$.

Intra- and inter-rater reliabilities were described by intraclass correlation coefficients (ICC) $)^{19,20}$. Three neurologists, who were experts in ataxia diagnosis, but did not have any previous knowledge about the patients' clinical progression or staging, participated in this phase. The first assessment was performed and filmed by rater 1 . All videos were performed with the same Canon high definition digital camera, set on a tripod $1 \mathrm{~m}$ away from the patient and at a height of $1.25 \mathrm{~m}$. For eye-movement analysis, the zoom was used to focus on the eyes. The videos were rescored by examiner 1 after 2-8 weeks ( for intra-rater analysis). Raters 2 and 3 scored all videos with the ICARS, for the inter-raters' analysis.

External consistency was based on Pearson's correlation coefficients between the ICARS and SARA ${ }^{15}$. Agreement verification and intra- and inter-raters scoring tendencies were described by Bland-Altman analysis ${ }^{21}$. The difference between measures must be zero or close to zero. The bias is a line that shows the mean difference of two measures (of examiners or evaluations of the same examiner). Lines closer to zero denote more reliable measures ${ }^{22}$.

\section{RESULTS}

Table 1 shows the words or sentences that were adapted to Brazilian culture. The ICARS mean scores of the three raters are shown in Table 2. Except for the posture domain, rater 3 tended to give higher scores in partial and total scores.

In the construct validity assessment, age and sex did not correlate with partial and total ICARS scores. Internal consistency assessment showed high values of Cronbach's alpha in the following variables: posture (0.919), kinetic function (0.902) and dysarthria (0.889) domains, but not for oculomotor changes (0.316). Table 3 shows the internal consistency of each question.

Table 1. Words or sentences translated and culturally adapted to the Brazilian version of the ICARS.

\begin{tabular}{|c|c|c|c|}
\hline Domain & Item & Original version in English & Final version in Portuguese \\
\hline \multirow{4}{*}{$\begin{array}{l}\text { Posture and gait } \\
\text { disturbances }\end{array}$} & 1.3 & Staggering & Vacilante \\
\hline & 1.5 & Two special sticks or with a stroller & Duas bengalas especiais ou com andador \\
\hline & 1.4 & Walking with autonomous support no longer possible & Não consegue andar independente sem apoio \\
\hline & 2.2 & Markedly reduced & Acentuadamente reduzida \\
\hline \multirow{2}{*}{ Kinetic functions } & 8.2 & Lowering the axis jerkily & Desliza com abalos espasmódicos no eixo \\
\hline & 14.2 & With recrossings & Passando dos limites \\
\hline \multirow{2}{*}{ Speech disorders } & 15 & A mischievous spectacle in Czechoslovakia & Um espetáculo audacioso na Checoslováquia \\
\hline & 16.1 & Suggestion of slurring & Sugestivo de fala empastada \\
\hline \multirow[b]{2}{*}{ Oculomotor disorders } & IV & Oculomotor disorders & Transtornos oculomotores \\
\hline & 19.1 & $\begin{array}{l}\text { Bilateral clear overshoot or } \\
\text { undershoot of the saccade }\end{array}$ & $\begin{array}{c}\text { Evidente hipermetria ou } \\
\text { hipometria bilateral da sacada }\end{array}$ \\
\hline
\end{tabular}

Table 2. The ICARS average scores of all examiners, by domain and total.

\begin{tabular}{lccccccccc}
\hline \multirow{2}{*}{ Domain } & \multicolumn{2}{c}{$\begin{array}{c}\text { Rater 1 (first } \\
\text { assessment) }\end{array}$} & \multicolumn{2}{c}{$\begin{array}{c}\text { Rater 1 (second } \\
\text { assessment) }\end{array}$} & \multicolumn{2}{c}{ Rater 2 } & Rater 3 \\
\cline { 2 - 9 } & Mean & SD & Mean & SD & Mean & SD & Mean & SD \\
\hline Posture and gait (34 points) & 15.70 & 8.41 & 15.56 & 8.52 & 15.54 & 8.46 & 15.38 & 8.74 \\
Kinetic functions (52 points) & 14.90 & 9.73 & 15.18 & 9.11 & 15.72 & 9.74 & 16.66 & 9.14 \\
Speech (8 points) & 2.90 & 1.60 & 2.84 & 1.72 & 2.87 & 1.74 & 3.08 & 1.77 \\
Oculomotor (6 points) & 3.20 & 1.31 & 3.28 & 1.17 & 3.07 & 1.90 & 3.70 & 1.04 \\
Total (100 points) & 36.70 & 18.34 & 36.85 & 17.94 & 37.20 & 17.97 & 38.82 & 18.41 \\
\hline
\end{tabular}


Table 3. Internal Consistency of the ICARS.

\begin{tabular}{lc}
\hline Question & Cronbach's alpha \\
\hline Q1 & 0.926 \\
Q2 & 0.926 \\
\hline Q3 & 0.924 \\
Q4 & 0.927 \\
\hline Q5 & 0.925 \\
\hline Q6 & 0.928 \\
\hline Q7 & 0.930 \\
\hline Q8 & 0.927 \\
Q9 & 0.932 \\
\hline Q10 & 0.925 \\
\hline Q11 & 0.927 \\
Q12 & 0.926 \\
\hline Q13 & 0.928 \\
\hline Q14 & 0.927 \\
\hline Q15 & 0.928 \\
\hline Q16 & 0.929 \\
\hline Q17 & 0.942 \\
\hline Q18 & 0.932 \\
\hline
\end{tabular}

All questions that made up the posture (alpha between 0.896 and 0.922 ) and kinetic function (alpha between 0.879 and 0.899) domains had high consistency with their respective domains. Analysis in the dysarthria domain was not possible, as there were only two questions. The questions in the oculomotor domain showed lower Cronbach's alpha coefficients (question $17=0.571$, question $18=0.287$ and question $19=-0.090)$, therefore, there was low internal consistency. However, Cronbach's alphas remained above 0.90 when each question was correlated with the total score, showing high internal consistency.

All ICC values were statistically significant. In the interrater reliability analysis, the ICC of the total score was $99.2 \%$ and in the intra-rater reliability analysis, the ICC was $99.6 \%$. The ICC ranged from $80 \%$ to $100 \%$ (Figures 1 and 2). The external consistency between the ICARS and SARA was calculated by Pearson's correlation tests $(r=95.3 \%$; $p<0.001)$ (Figure 3).

The Bland-Altman graphs showed no trends in the evaluations performed by the same rater and between the three raters, because the points were randomly distributed. There was a significant difference (bias) in the evaluations of raters 1 and 3 in the kinetic, dysarthria, oculomotor and total scores. Intra- and inter-raters 1 and 2 analyses did not show any bias. Some graphs showed points outside the upper and lower confidence intervals, but most points were positioned \pm 2 standard deviations.
Inter-rater reliability of ICARS

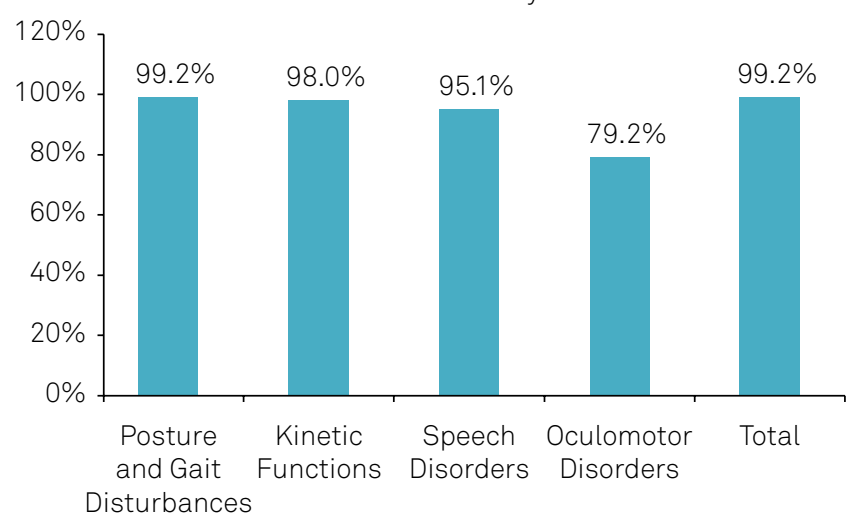

Figure 1. Inter-rater reliability of ICARS.

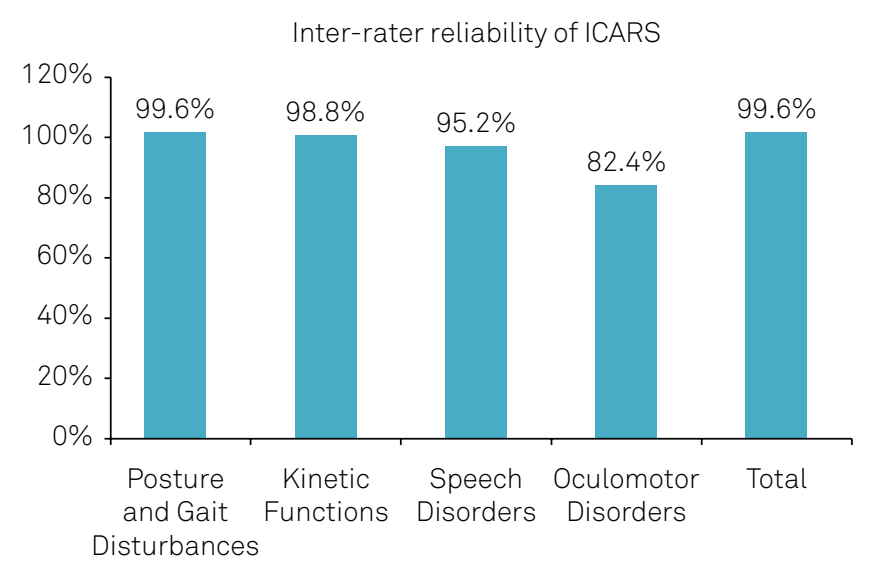

Figure 2. Intra-rater reliability of ICARS.

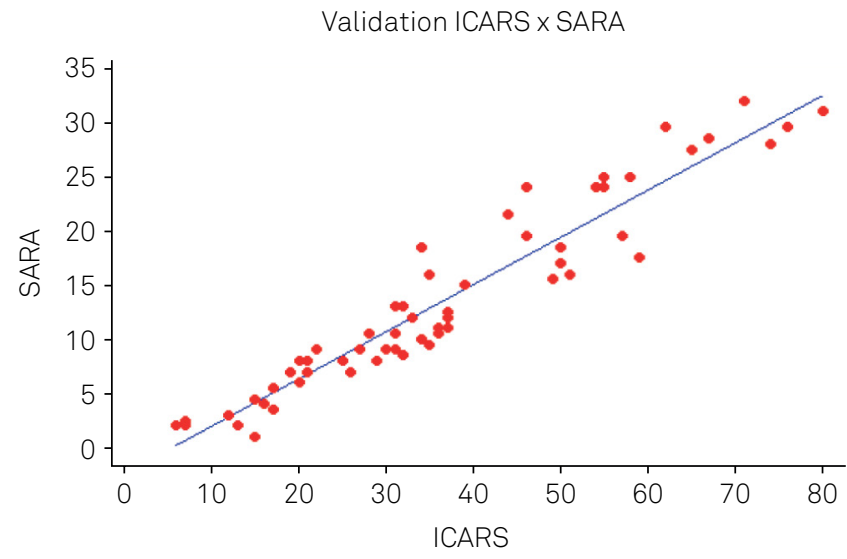

Figure 3. External consistency between the ICARS and SARA.

\section{DISCUSSION}

The ICARS was translated into Brazilian Portuguese with good construct validity, high internal consistency and considerable intra- and inter-rater reliabilities. We also found high correlation with the SARA. The few translation divergences that emerged during the process were easily corrected by the translators and the consensus was established. 
Several rating scales have been used and validated for evaluation of ataxias. The ICARS is a widely-used scale that quantifies several domains of cerebellar disorders: postural and stance disorders, limb ataxia, dysarthria and oculomotor disorders ${ }^{11}$. The scale was created in 1997 by the World Federation of Neurology Committee to provide a standardized clinical classification system to quantify deficits caused by cerebellar ataxia ${ }^{11}$. The ICARS has already been validated (English version) for evaluation of patients with multiple system atrophy and Parkinson's disease ${ }^{23}$, SCAs and Friedreich's ataxia $^{18,24,25}$ and focal cerebellar lesions ${ }^{26}$.

The scale met the criteria of reliability and validity in its English version. However, the scale also had some problems in practicality and subscales items ${ }^{23}$. The use of the ICARS in clinical practice in patients with cerebellar ataxias has been criticized among professionals for being too long and having a great number of questions ${ }^{27}$. Indeed, Schmitz-Hubsch and coworkers $^{18}$ evaluated the metric properties of the ICARS. The scale was described as very long for application by the health professionals, with an average estimated time of 21 minutes. Our study showed that practicing the clinical evaluation in patients with the ICARS decreased the time of application of the scale from 25 to 12 minutes, on average, comparing the beginning to the end of the live evaluations.

Our study also showed that the Brazilian version of the ICARS detected ataxia even in patients with very mild clinical signs, in our sample of SCA patients, which is an important diagnostic challenge. A previous report also described its sensitivity to a range of ataxia severities, from very mild to severe ${ }^{24}$.

For the validation of the Brazilian version of the ICARS, the individual characteristics of the patients' age and sex were initially analyzed, to ensure that these did not influence the scoring of the scale. In construct validity analyses, no correlations between sex and ICARS scores or age and ICARS scores were found. We did not perform other correlations to verify the validity of the construct. Schmitz-Hubsch et al. described a moderate correlation between ICARS scores and the duration of the disease ${ }^{18}$.

Regarding the internal consistency analysis, high correlations between the domains and the total score were found, except for the oculomotor domain. By excluding questions from the oculomotor domain (17-19) and analyzing the full value of Cronbach's alpha from the scale, we found a slight increase in the total alpha value. Similar results were described in a European study with 156 patients with SCA. The authors considered the ICARS internal consistency to be adequate with a Cronbach's alpha of 0.95, but with the same increase in the alpha value excluding the oculomotor domain ${ }^{18}$. A high internal consistency has also been found when evaluating patients with Friedrich's ataxia ${ }^{25}$ and with focal cerebellar lesions ${ }^{26}$.

Regarding the reliability analysis of the Brazilian version of the ICARS, our results showed acceptable levels of this criterion. The domain with the lowest ICC for the intra-rater (82.4\%) and inter-rater (79.2\%) was the oculomotor. According to the raters of the present study, it was difficult to evaluate ocular movement through the video. This was also observed in the intra-rater evaluation performed by the same physician. Another study also reported difficulty in oculomotor evaluation through videos in 22 patients with hereditary ataxia. ${ }^{24}$ It is reported in the literature that ICC values between $75 \%$ and $100 \%$ show a high correlation between the statistically significant data ${ }^{24}$. Therefore, despite the ICC of oculomotor domain being the lowest value, it still gives the ICARS an excellent reproducibility of results.

In a larger study with 156 patients, the lowest value of ICC was for the domain of dysarthria $(\mathrm{ICC}=76 \%)^{18}$. In Brazil, our examiners had no difficulty analyzing speech through the videos and the domain of speech disorders had a high intra(95.2\%) and inter-rater (95.1\%) ICC.

Our results showed a marked correlation between the ICARS and the SARA (the gold-standard scale for SCA assessment). The SARA is a more compact scale, which evaluates eight items and addresses the same signs and symptoms of the ICARS, except for oculomotor disorders. A significant correlation between the ICARS and SARA scores was found in a study by Yabe et $\mathrm{al}^{27}$. However, our results are in disagreement with a previous study by our group, which did not find a significant correlation between these scales. Indeed, the small number of patients in our previous study, on a scale with a larger number of items such as the ICARS, may explain the negative correlation between the scales ${ }^{10}$.

Intra- and inter-rater Bland-Altman graphs show the agreement in each domain and in the total score. The intrarater analysis showed low bias ( $p>0.05)$ and the mean differences between evaluations were close to zero in all graphs. When the relationship between the mean scores of the same rater (direct evaluation with the patient and video evaluation) were investigated, a strong correlation was observed for partial and total scores. This analysis also showed agreement between raters 1 and 2, with strong correlation (ICC) and concordance with the Bland-Altman graph (low bias). Inter-rater analysis showed that, although rater 1 maintained good agreement with rater 2 , raters 1 and 3 disagreed. Rater 3 assigned higher scores in all domains, except for the posture domain.

Our results showed more discordant findings in limb kinetic functions, speech disorders and oculomotor disorder assessments. Adjectives such as "slightly, clearly or severely", "slightly, clearly, extremely or completely" and "suggestion, definitive or severe" are used to quantify signs or symptoms and may be subjective. On the other hand, the posture and gait disturbances domain has more direct response options, for example, whether a tandem walk can be performed, supervision is needed, or wall support, walker or wheelchair are used. The objectivity in these answers explains the agreement between the examiners in the posture and gait domain and the partial disagreement between examiners in the other domains. 
Santos et al. ${ }^{28}$ performed the translation and transcultural adaptation of the ICARS, without the Brazilian Portuguese validation. Moreover, the study was performed with only five patients. According to the guidelines for transcultural adaptation, the inclusion of 30 to 40 patients is necessary ${ }^{13}$. The methodology described to validate our ICARS version in Brazil is in accordance with the literature and presents a highly representative sample, as the largest validation study of the ICARS included 156 patients with SCA ${ }^{18}$. In the present study, the ICARS was subjected to the evaluation of construct validity and agreement between measurements by BlandAltman graphs.

This study has some potential limitations. The selected ataxic patients exclusively had a diagnosis of SCA. As a result, other hereditary ataxias were not evaluated in the present study.

In conclusion, this study translated and adapted the ICARS to Brazilian Portuguese and validated it for the Brazilian population with SCAs. The results of this study justify the use of this version of the ICARS for patients with SCA

\section{References}

1. Schöls L, Bauer P, Schmidt T, Schulte T, Riess O. Autosomal dominant cerebellar ataxias: clinical features, genetics, and pathogenesis. Lancet Neurol. 2004 May;3(5):291-304. https://doi.org/10.1016/S1474-4422(04)00737-9

2. Akbar U, Ashizawa T. Ataxia. Neurol Clin. 2015 Feb;33(1):225-48 https://doi.org/10.1016/j.ncl.2014.09.004

3. Kim JS, Cho JW. Hereditary cerebellar ataxias: a Korean perspective.J Mov Disord. 2015 May;8(2):67-75. https://doi.org/10.14802/jmd.15006

4. Depondt C, Donatello S, Rai M, Wang FC, Manto M, Simonis $\mathrm{N}$ et al. MME mutation in dominant spinocerebellar ataxia with neuropathy (SCA 43). Neurol Genet. 2016 Oct;2(5):e94. https://doi.org/10.1212/NXG.0000000000000094

5. Sun YM, Lu C, Wu ZY. Spinocerebellar ataxia: relationship between phenotype and genotype: a review. Clin Genet. 2016 Oct;90(4):305-14. https://doi.org/10.1111/cge.12808

6. Nibbeling EA, Duarri A, Verschuuren-Bemelmans CC, Fokkens MR, Karjalainen JM, Smeets CJ et al. Exome sequencing and network analysis identifies shared mechanisms underlying spinocerebellar ataxia. Brain. 2017 Nov;140(11):2860-78. https://doi.org/10.1093/brain/awx251

7. Watson LM, Bamber E, Schnekenberg RP, Williams J, Bettencourt C, Lickiss $J$ et al. Dominant Mutations in GRM1 cause spinocerebellar ataxia type 44. Am J Hum Genet. 2017 Nov;101(5):866. https://doi.org/10.1016/j.ajhg.2017.10.008

8. Pedroso JL, de Resende Pinto WB, de Souza PV, Andriotti C, Stavale JN, Barsottini OG. Anterior horn degeneration in Machado-Joseph disease. J Neurol Sci. 2016 Sep;368:290-1. https://doi.org/10.1016/j.jns.2016.07.037

9. Sarro L, Nanetti L, Castaldo A, Mariotti C. Monitoring disease progression in spinocerebellar ataxias: implications for treatment and clinical research. Expert Rev Neurother. 2017 Sep;17(9):919-31. https://doi.org/10.1080/14737175.2017.1364628

10. Braga-Neto P, Godeiro-Junior C, Dutra LA, Pedroso JL, Barsottini OG. Translation and validation into Brazilian version of the Scale of the Assessment and Rating of Ataxia (SARA). Arq Neuropsiquiatr. 2010 Apr;68(2):228-30. https://doi.org/10.1590/S0004-282X2010000200014

11. Trouillas P, Takayanagi T, Hallett M, Currier RD, Subramony SH, Wessel K et al. International Cooperative Ataxia Rating Scale for pharmacological assessment of the cerebellar syndrome. J Neurol Sci. 1997 Feb;145(2):205-11. https://doi.org/10.1016/S0022-510X(96)00231-6

12. Guillemin F, Bombardier C, Beaton D. Cross-cultural adaptation of health-related quality of life measures: literature review and proposed guidelines. J Clin Epidemiol. 1993 Dec;46(12):1417-32. https://doi.org/10.1016/0895-4356(93)90142-N

13. Beaton DE, Bombardier C, Guillemin F, Ferraz MB. Guidelines for the process of cross-cultural adaptation of self-report measures. Spine. 2000 Dec;25(24):3186-91. https://doi.org/10.1097/00007632-200012150-00014
14. Tavakol M, Dennick R. Making sense of Cronbach's alpha. Int J Med Educ. 2011 Jun;2:53-5. https://doi.org/10.5116/ijme.4dfb.8dfd

15. Kirkwood BR, Sterne JA. Essential medical statistics. 2nd ed. Massachusetts: Blackwell Science; 2006.

16. Strauss ME, Smith GT. Construct validity: advances in theory and methodology. Annu Rev Clin Psychol. 2009;5(1):1-25. https://doi.org/10.1146/annurev.clinpsy.032408.153639

17. Marx RG, Menezes A, Horovitz L, Jones EC, Warren RF. A comparison of two time intervals for test-retest reliability of health status instruments. J Clin Epidemiol. 2003 Aug;56(8):730-5. https://doi.org/10.1016/S0895-4356(03)00084-2

18. Schmitz-Hübsch T, Tezenas du Montcel S, Baliko L, Boesch S, Bonato S, Fancellu R et al. Reliability and validity of the International Cooperative Ataxia Rating Scale: a study in 156 spinocerebellar ataxia patients. Mov Disord. 2006 May;21(5):699704. https://doi.org/10.1002/mds.20781

19. Fleiss JL. The design and analysis of clinical experiments. New York: Wiley; 1986

20. Vieira S. Bio estatística: tópicos avançados. 2nd ed. Rio de Janeiro: Campus; 2004.

21. Altman DG, Bland JM. Measurement in medicine: the analysis of method comparison studies. Statistician. 1983;32(3):307-17. https://doi.org/10.2307/2987937

22. Hirata VN, Camey SV. Análise de concordância entre métodos de Bland-Altman. Rev HCPA. 2009;29(3):261-88.

23. Tison F, Yekhlef F, Balestre E, Chrysostome V, Quinn N, Wenning GK et al. Application of the International Cooperative Ataxia Scale rating in multiple system atrophy. Mov Disord. 2002 Nov;17(6):1248-54. https://doi.org/10.1002/mds.10290

24. Storey E, Tuck K, Hester R, Hughes A, Churchyard A. Interrater reliability of the International Cooperative Ataxia Rating Scale (ICARS). Mov Disord. 2004 Feb;19(2):190-2. https://doi.org/10.1002/mds.10657

25. Cano SJ, Hobart JC, Hart PE, Korlipara LV, Schapira AH, Cooper JM. International Cooperative Ataxia Rating Scale (ICARS): appropriate for studies of Friedreich's ataxia? Mov Disord. 2005 Dec;20(12):1585-91. https://doi.org/10.1002/mds.20651

26. Schoch B, Regel JP, Frings M, Gerwig M, Maschke M, Neuhäuser M et al. Reliability and validity of ICARS in focal cerebellar lesions. Mov Disord. 2007 Nov;22(15):2162-9. https://doi.org/10.1002/mds.21543

27. Yabe I, Matsushima M, Soma H, Basri R, Sasaki H. Usefulness of the Scale for Assessment and Rating of Ataxia (SARA). J Neurol Sci. 2008 Mar;266(1-2):164-6. https://doi.org/10.1016/j.jns.2007.09.021

28. Santos ME. Contenças TS, Santos TMS, Silva EC, Antunes GL. Tradução e adaptaçãoo cultural da escala ICARS-BR na língua portuguesa do Brasil. J Health Sci Inst. 2017;35(1):44-8. 


\section{APPENDIX}

\section{Brazilian Portuguese version of the ICARS}

\section{Escala Cooperativa Internacional para Avaliação das Ataxias (ICARS)}

\section{Distúrbios de Postura e da Marcha}

Capacidade de Andar

(Observada durante um teste de 10 metros incluindo uma meia-volta, cerca de 1,5 metro da parede.)

0 : Normal

1: Quase normal, anda naturalmente, mas é incapaz de andar com os pés na posição tandem

2: Anda sem apoio, mas de forma claramente anormal e irregular

3: Anda sem apoio, mas vacilante; dificuldade na meia-volta

4: Não consegue andar independentemente, o paciente usa o apoio ocasional na parede no teste dos 10 metros

5: Só é possível andar com uma bengala

6: Só é possível andar com duas bengalas especiais ou um andador

7: Anda apenas com acompanhante

8: Andar é impossível, mesmo com acompanhante (cadeira de rodas)

Pontuação:

\section{Velocidade da marcha}

(Observada nos pacientes com pontuação 1-3 no item anterior; pontuar como 4 automaticamente se o paciente tiver obtido 4 ou mais no item anterior.)

0 : Normal

1: Levemente reduzida

2: Reduzida

3: Extremamente reduzida

4: Não consegue andar independentemente sem apoio

Pontuação:

\section{Capacidade de ficar em pé, olhos abertos}

(O paciente é primeiramente solicitado a tentar ficar em pé sobre um dos pés. Se for impossível, deve tentar ficar com os pés em tandem. Se não for possível, deve ficar em pé com os pés juntos. Na posição natural, o paciente é solicitado a encontrar uma posição confortável em pé.)

0: Normal: capaz de ficar em pé sobre apenas um dos pés por mais de 10 segundos

1: Capaz de ficar em pé em tandem, mas não é mais capaz de ficar sobre apenas um dos pés por mais de 10 segundos

2: Capaz de ficar em pé com os pés juntos, mas não é mais capaz de ficar em pé com os pés na posição tandem

3: Não é mais capaz ficar em pé com os pés juntos, mas é capaz de ficar em pé na posição natural sem apoio, sem oscilação ou com oscilação moderada

4: Fica em pé na posição natural sem apoio, com oscilações e correções consideráveis

5: Incapaz de ficar em pé na posição natural sem o apoio firme de um braço

6: Totalmente incapaz de ficar em pé, mesmo com apoio firme dos dois braços

Pontuação:

\section{Envergadura dos pés na posição natural sem apoio, olhos abertos}

(O paciente é solicitado a encontrar uma posição confortável. Assim, a distância entre os maléolos mediais é medida.)

0: Normal $(<10 \mathrm{~cm})$

1: Discretamente aumentada $(>10 \mathrm{~cm})$

2: Claramente aumentada $(25 \mathrm{~cm}<$ distância $<35 \mathrm{~cm})$

3: Gravemente aumentada $(>35 \mathrm{~cm})$

4: Ficar em pé na posição natural é impossível

Pontuação:

\section{Oscilação do corpo com os pés unidos, olhos abertos \\ 0 : Normal \\ 1: Oscilações leves}


2: Oscilações moderadas ( $<10 \mathrm{~cm}$ no nível da cabeça)

3: Oscilações graves (> $10 \mathrm{~cm}$ no nível da cabeça), ameaçando a posição em pé

4: Queda imediata

Pontuação:

\section{Oscilação do corpo com os pés unidos, olhos fechados}

0 : Normal

1: Oscilações leves

2: Oscilações moderadas ( $<10 \mathrm{~cm}$ no nível da cabeça)

3: Oscilações graves (> 10 cm no nível da cabeça), ameaçando a posição em pé

4: Queda imediata

Pontuação:

\section{Qualidade da posição sentada}

(Coxas unidas, numa superfície rígida, braços cruzados.)

0 : Normal

1: Com leves oscilações do tronco

2: Com oscilações moderadas do tronco e das pernas

3: Com desequilíbrio grave

4: Impossível

Pontuação:

Pontuação da postura e da marcha (pontuação estática):

\section{Funções cinéticas}

\section{Teste joelho-tíbia (decomposição de movimento e tremor intencional)}

(O teste é realizado na posição supina, mas a cabeça é inclinada de modo que o controle visual seja possível. O paciente é requisitado a elevar uma perna e colocar o calcanhar sobre o joelho. Então, deslizar o calcanhar sobre a superfície tibial anterior da perna que está em repouso, em direção ao tornozelo. Ao atingir a articulação do tornozelo, a perna é elevada novamente na altura de aproximadamente $40 \mathrm{~cm}$ e a ação é repetida. Ao menos três repetições com cada membro devem ser realizadas para a avaliação apropriada.)

0 : Normal

1: Desliza para baixo, num eixo contínuo, mas o movimento é decomposto em várias fases (sem abalos espasmódicos efetivos) ou é anormalmente lento

2: Desliza para baixo, com abalos espasmódicos, no eixo

3: Desliza para baixo, com abalos espasmódicos lateralizados

4: Desliza para baixo, com abalos espasmódicos lateralizados extremamente fortes, ou o teste é impossível

Pontuação do membro direito:

Pontuação do membro esquerdo:

\section{Tremor de ação no teste calcanhar-joelho}

(Mesmo teste anterior: o tremor de ação do calcanhar sobre o joelho é especificamente observado quando o paciente mantém o calcanhar sobre o joelho por alguns segundos antes de deslizar sobre a superfície tibial anterior; o controle visual é requerido.)

0 : Sem dificuldade

1: O tremor para imediatamente quando o calcanhar alcança o joelho

2: O tremor para em menos de 10 segundos após o calcanhar alcançar o joelho

3: O tremor continua por mais de 10 segundos após o calcanhar alcançar o joelho

4: O tremor é ininterrupto ou o teste é impossível

Pontuação do membro direito:

Pontuação do membro esquerdo:

\section{Teste índex-nariz: decomposição e dismetria}

(O sujeito senta na cadeira; a mão repousa sobre o joelho antes de iniciar o movimento; controle visual é requerido. Três repetições com cada membro devem ser realizadas para a avaliação apropriada.)

0 : Sem dificuldade

1: Movimento oscilante sem decomposição

2: Movimento segmentado em duas fases e/ou dismetria moderada ao alcançar o nariz

3: Movimento segmentado em mais de duas fases e/ou dismetria considerável ao alcançar o nariz 
4: Dismetria impede que o paciente alcance o nariz

Pontuação do membro direito:

Pontuação do membro esquerdo:

\section{Teste índex-nariz: tremor de intenção do dedo}

(O tremor em estudo é o que surge durante a fase balística do movimento; o paciente senta confortavelmente, com a mão repousando sobre a coxa; o controle visual é requerido; três repetições com cada membro devem ser realizadas para a avaliação apropriada.)

0: Sem dificuldade

1: Leve desvio do movimento

2: Tremor moderado com amplitude estimada $<10 \mathrm{~cm}$

3: Tremor com amplitude estimada entre $10 \mathrm{~cm}$ e $40 \mathrm{~cm}$

4: Tremor grave com amplitude estimada $>40 \mathrm{~cm}$

Pontuação do membro direito:

Pontuação do membro esquerdo:

\section{Teste índex-índex (tremor de ação e/ou instabilidade)}

(O paciente sentado é solicitado a manter seus dois dedos indicadores apontando medialmente um para o outro por cerca de 10 segundos, a uma distância de cerca de $1 \mathrm{~cm}$, no nível do tórax, sob controle visual.)

0 : Normal

1: Instabilidade leve

2: Oscilações moderadas do dedo com amplitude estimada $<10 \mathrm{~cm}$

3: Oscilações consideráveis do dedo com amplitude estimada entre $10 \mathrm{~cm}$ e $40 \mathrm{~cm}$

4: Movimentos bruscos $>40 \mathrm{~cm}$ de amplitude

Pontuação do membro direito:

Pontuação do membro esquerdo:

\section{Movimentos alternados de pronação-supinação}

(O sujeito, sentado confortavelmente na cadeira, é solicitado a manter um dos braços à frente e paralelo ao chão ( $90^{\circ}$ flexão de ombro e extensão de cotovelo). Em seguida, é solicitado a realizar movimentos alternados de pronação e supinação de antebraço. Cada mão é movida e avaliada separadamente.)

0 : Normal

1: Levemente irregular e lentificado

2: Claramente irregular e lentificado, mas sem oscilação do cotovelo

3: Movimento extremamente irregular e lentificado, com oscilação do cotovelo

4: Movimento completamente desorganizado ou impossível

Pontuação do membro direito:

Pontuação do membro esquerdo:

\section{Desenho da Espiral de Arquimedes num padrão pré-desenhado}

(O sujeito instalado confortavelmente em frente a uma mesa, com a folha de papel fixa para evitar artefatos. O sujeito é solicitado a realizar a tarefa sem tempo estabelecido. As mesmas condições devem ser usadas em cada exame: mesma mesa e caneta. A mão dominante deve ser examinada. Para avaliação, veja os exemplos no final dessa seção.)

0 : Normal

1: Alteração e decomposição, a linha sai do padrão levemente, mas sem desvios hipermétricos

2: Linha completamente fora do padrão, passando dos limites do original, mas sem cruzar por cima do que já foi desenhado e sem desvios hipermétricos

3: Distúrbios intensos devido à hipermetria e decomposição

4: Desenho completamente desorganizado ou impossível

Pontuação:

Pontuação cinética (coordenação de membros):

\section{Distúrbios da fala}

15. Disartria: fluência da fala

(O paciente é solicitado a repetir várias vezes uma sentença padrão, sempre a mesma, por exemplo, Um espetáculo audacioso na Checoslováquia)

0 : Normal

1: Modificação leve da fluência

2: Modificação moderada da fluência 


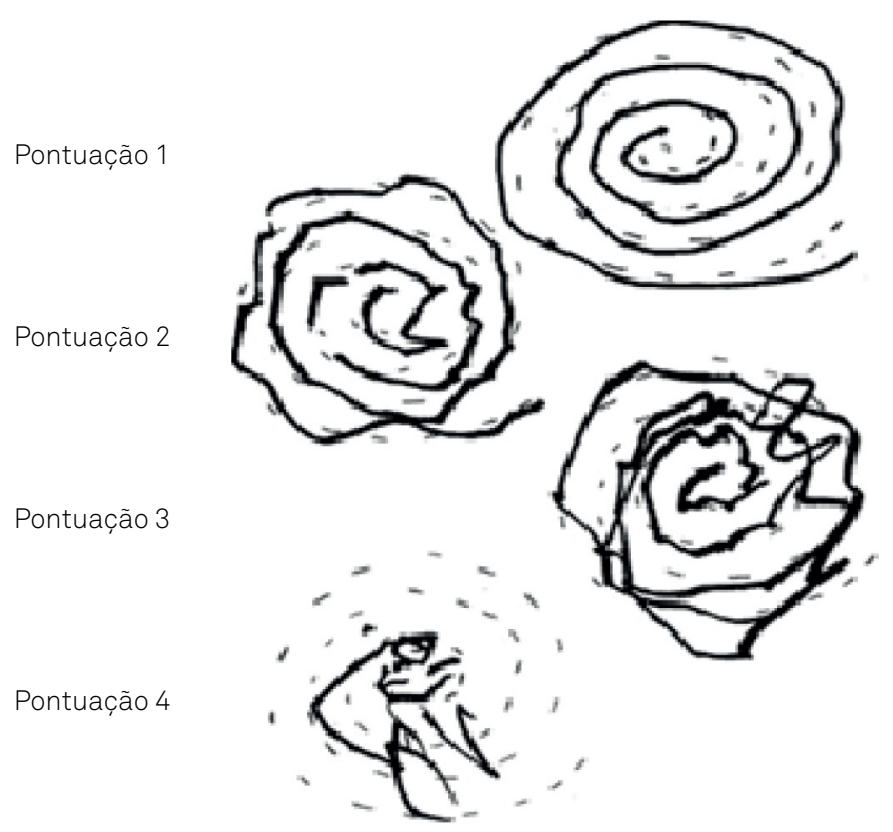

Figure 1. Pontuação dos distúrbios de desenho no teste da espiral de Arquimedes.

3: Considerável lentificação e fala disártrica

4. Sem fala

Pontuação:

\section{Disartria: clareza da fala}

0 : Normal

1: Sugestivo de fala empastada

2: Definitivamente empastada, a maioria das palavras inteligível

3: Gravemente empastada, fala ininteligível

4. Sem fala

Pontuação:

Pontuação da disartria:

\section{Transtornos oculomotores}

\section{Nistagmo evocado pelo olhar}

(O sujeito é solicitado a olhar lateralmente para o dedo do examinador: os movimentos avaliados são principalmente horizontais, mas podem ser oblíquos, rotatórios ou verticais.)

0: Normal

1: Transitório

2: Persistente, mas moderado

3: Persistente e grave

Pontuação:

\section{Anormalidades do acompanhamento ocular}

(O paciente é solicitado a seguir o movimento lento e lateral realizado pelo dedo do examinador.)

0: Normal

1: Levemente sacádico

2: Claramente sacádico

Pontuação: 


\section{Dismetria da sacada}

(Os dois dedos indicadores do examinador são colocados em cada campo visual temporal do paciente, cujos olhos estão na posição primária. O paciente é, então, solicitado a olhar lateralmente para os dedos, à direita e à esquerda. A média de hipermetria ou hipometria para os lados é, então, estimada.)

0 : Ausente

1: Evidente hipermetria ou hipometria bilateral da sacada

Pontuação:

Pontuação do movimento oculomotor: 